\title{
Students' Views on ICT for English Learning During the Pandemic
}

\section{Junko Yamamoto}

Osaka Jogakuin University

\section{Brian Teaman \\ Osaka Jogakuin University}

\section{Reference Data}

Yamamoto, J. \& Teaman, B. (2021). Students' views on ICT for English learning during the pandemic. In P. Clements, R. Derrah, \& P. Ferguson (Eds.), Communities of teachers \& learners. JALT. https://doi.org/10.37546/JALTPCP2020-42

The 2020 academic year had schools throughout Japan and the world pivot to online education because of the Covid-19 pandemic. As our research site is a technology-friendly university, having started universal iPad use in 2012, we knew our students had the tools and necessary skills to get online. We wanted to know how our students received online classes and what impact the 2020 online courses had on their confidence in ICT (Information and Communication Technology) skills and motivation to learn both for online courses and out-of-class learning. The interviews showed increased confidence in ICT skills. The motivation to learn was generally positive, although demotivating factors were also observed. For the most part, interviewees got used to the new learning style and carried out tasks successfully.

2020年度は、Covid-19 パンデミックのために世界中の学校でオンライン教育が行われた。本研究が行われた大学では ICT (情報通信技術)を多用しており、2012年からiPadによる英語教育を行つている。そのためすべての学生がオンライン授業 に対応するツールとそれに必要なスキルを持っていた。その学生達が、2020年春学期のオンラインクラスをどのように受講し たのか、オンラインコースがICTスキルへの自信や英語学習動機などにどのような影響を与えたかを調査した。インタビュー

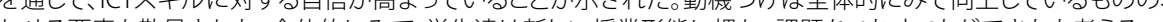
わせる要素も散見された。全体的にみて、学生達は新しい授業形態に慣れ、課題をこなすことができたと考える。 $\neg$ he 2020 academic year forced teachers worldwide to move to online learning

Lecause of the COVID-19 pandemic. At the institution where this research took place, all students had a device they could use for their classes as the school has distributed iPads to all incoming students since 2012. Faculty-developed eBooks, along with a variety of standard applications, were available for students to draw upon immediately. Surveys conducted with previous groups of students at this university show that students who received ICT-based English education were generally positive about iPad use for language study (e.g., Swenson et al., 2014). Also, they exhibited a high tolerance for technological ambiguity, meaning they were observed to be willing to use new technology, which is essential when adapting to a new environment (Furnham \& Marks, 2013).

We were curious to know how our students who had to face the sudden transition to online classes characterized ICT use for English learning. They had iPads and basic ICT skills to draw upon while teachers used a variety of platforms to deliver lectures and distribute materials, including Google Meet, Zoom, and YouTube, providing lessons synchronously, asynchronously, or in combination. Communication between students and teachers was mediated using Moodle, Google Classrooms, email, and the Line messaging app. We decided to inquire how the school's emphasis on ICT-based education affected students' English learning in this situation. Furthermore, we decided to see if we can observe any shifts in motivation given the pivot to online education.

Use of ICT, especially Computer-Mediated-Communication (CMC) and Webenhanced Language Learning, can have positive effects on learners' motivation

(Cummings, 2004; Ritchie \& Black, 2012; Warschauer \& Healey, 1998). This is because, as Ritchie and Black (2012) wrote, CMC can "activate various learning styles and multiple intelligences, promote collaboration between students, and give students access to a variety of authentic material" (p. 350). Ushioda (2013) maintains that mobile assisted language learning (MALL) plays an important role as "learning with mobile technologies can engage learners' emotions and feelings in a positive way” (p. 3). 
JALT2020

COMMUNITIES OF
TEACHERS \& LEARNERS

Yamamoto (2020b) indicated that all four interviewees initially had difficulties adopting new ICT skills. However, they gradually overcame these obstacles through the use of these skills in English classes, ICT classes, and interactions with their peers and teachers, resulting in increased motivation to learn English. In a different study, Yamamoto (2020a) revealed that e-learning-based educational intervention did not improve participants' motivation. One possible reason is that as mobile technology is related to internally driven motivation, pushing students to work on mobile devices can be counterproductive. Ushioda (2013) asserts that "the use of mobile technologies should best be left as a matter of free choice and individual autonomy for language learners (p. 2)."

Thus, we wanted to explore the ways in which students' familiarity with technology might have helped them adapt to online instruction and to find out how this affected their motivation to learn English.

\section{Research Questions}

Our interests in the relationship between ICT based English education and students' motivation and how they coped with the new challenges of online English classes led to the following research questions.

1. How do students characterize ICT use for English learning during the emergency online Spring term?

2. How have students' ICT skills changed during the online Spring term?

3. Which devices did students utilize for their remote classes?

4. What impact did the online Spring term courses have on students' motivation to study English?

\section{Method}

Interviews were conducted with five students in a department of English and international studies. This study was conducted in September through October, 2020, after the school resumed face-to-face classes.

\section{Participants}

Interview participants were invited from a pool of students that had been enrolled in two remedial-type basic grammar classes in the 2019 academic year. They had participated in previous research that investigated the relationship between e-learning and motivation (Yamamoto, 2020a). Based on their most recent TOEIC IP test scores, three students from each of the upper, middle, and lower third of the class, were randomly invited to participate. Five students agreed. Their entry and most recent TOEIC ${ }^{\circ} I P$ scores (taken right after the 2020 Spring term) appear in Table 1. All interviewees gave informed consent, and the project was cleared with the university's institutional review board.

Table 1

Interview Participants' TOEIC ${ }^{\circledast} I P$ Scores by Test Administration

\begin{tabular}{lccc}
\hline Student Name & Entry: April, 2019 & August, 2020 & Gain \\
\hline Yoko (upper) & 240 & 575 & 335 \\
Ami (middle) & 275 & 425 & 150 \\
Mie (middle) & 245 & 425 & 180 \\
Seiko (lower) & 185 & 385 & 200 \\
Chie (lower) & 240 & 385 & 170 \\
\hline
\end{tabular}

Note. TOEIC $=$ Test of English for International Communication, IP = Institutional Program, Names are all pseudonyms.

\section{Interview Protocols}

All interviews were conducted in Japanese. One researcher conducted semi-structured interviews with participants $(N=5)$ separately to explore participants' thoughts about their ICT use during the pandemic. Questions included the following probes:

1. Which devices did you use? Why?

2. Tell me about the online classes? What were the merits? What were the demerits?

3. During online courses, how did you solve ICT problems?

4. How did you use your ICT for out-of-class study during Spring term?

5. How would you rate your confidence in your ICT skills?

6. How did ICT use affect your motivation to learn? 
JALT2020

COMMUNITIES OF
TEACHERS \& LEARNERS

\section{Interview Data Analysis}

Students' answers to the interview questions were recorded, transcribed, and translated into English. Then their statements were cut into discrete groups of usually one or two sentences. The tokens totaled 360 (Yuko, 46, Ami, 54, Mie 94, Seiko 67, and Chie 99).

They were then coded for comments regarding devices and then other references to ICT. The method used was based on an inductive approach of grounded theory (Strauss \& Corbin, 1998). These ICT comments were further coded for whether they referred to English or more general aspects of ICT. Furthermore, they were coded for references to motivation, and finally, positive or negative affective positions were noted. In the following section, we will look at interviewees' comments as they relate to our research questions. For each area of interest, shown in Table 2, there will be tables showing the number of comments for each student. For Tables 3, 5, and 8, a Chi-square residual analysis was conducted on the frequency counts for each section. This analysis tested the difference between the observed and expected values for each section, using the standardized residuals which are normally distributed (Agresti, 2002) with BenjaminiHochberg correction for multiple comparisons. Significance was defined as $p<.05(*)$ and, $p<.01(* *)$. In Tables 6 and 9, Fisher's exact tests were conducted on the ratio of positive to negative comments. Js-STAR version 8.1.1 j was used for both analyses. Tables 4,7 , and 10 show typical comments.
Table 2

Areas Asked and Definition

\begin{tabular}{|c|c|}
\hline Areas Asked About & Definition \\
\hline Devices & $\begin{array}{l}\text { This refers to the device or devices that a student used for online } \\
\text { classes. Utterances need to contain words about the kind of } \\
\text { hardware she was using. }\end{array}$ \\
\hline $\begin{array}{l}\text { ICT's impact on } \\
\text { English learning }\end{array}$ & $\begin{array}{l}\text { This refers to ICT's influence on both in-class and out-of-class } \\
\text { English learning. Utterances need to contain words about ICT } \\
\text { used for English learning. }\end{array}$ \\
\hline $\begin{array}{l}\text { ICT's impact on } \\
\text { English learning } \\
\text { motivation }\end{array}$ & $\begin{array}{l}\text { This refers to ICT's influences on intrinsic or extrinsic } \\
\text { motivation to learn English. Utterances need to contain words } \\
\text { which clearly indicate motivation related to English learning. }\end{array}$ \\
\hline $\begin{array}{l}\text { ICT's impact in } \\
\text { general }\end{array}$ & $\begin{array}{l}\text { This refers to the influence that ICT has on one's learning in } \\
\text { general. Utterances need to contain words about ICT affecting } \\
\text { her learning in general. }\end{array}$ \\
\hline $\begin{array}{l}\text { ICT's impact on } \\
\text { motivation }\end{array}$ & $\begin{array}{l}\text { Similar to ICT impact on English learning motivation (see above) } \\
\text { but related to influences that ICT gives on one's motivation in } \\
\text { general and not specifically about English. Utterances need to } \\
\text { contain words about ICT affecting her motivation in general. }\end{array}$ \\
\hline
\end{tabular}

Devices

\section{Results}

Table 3 shows that most comments regarding iPads were positive while those about computers were mostly negative. All the comments about smartphones were positive. Mie, Chie, Seiko, and Ami primarily used their iPads, while Yuki mainly used her computer. The ease of using iPads was expressed by the four students. Troubles they had with computers seem to come from their less frequent use of them. In other words, they might show a more positive attitude towards computers with increased familiarity. Examples of utterances coded for device comments are shown in Table 4. 


\section{JALT2020}

COMMUNITIES OF

Table 3

Device Comment Coding

\begin{tabular}{lcccc}
\hline $\begin{array}{l}\text { Comment } \\
\text { Polarity }\end{array}$ & iPads & Computers & Smartphones & Total \\
\hline Positive & $32(82 \%)$ & $3(27 \%)$ & $13 *(100 \%)$ & $48(76 \%)$ \\
Negative & $7(18 \%)$ & $8 *(73 \%)$ & $0(0 \%)$ & $15(24 \%)$ \\
Total & $39(100 \%)$ & $11(100 \%)$ & $13(100 \%)$ & $63(100 \%)$ \\
\hline
\end{tabular}

Note. $*=p<.05$.

Figure 1

On iPads

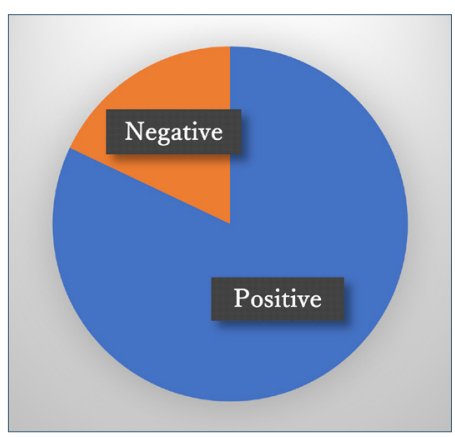

Figure 3

On Smartphones

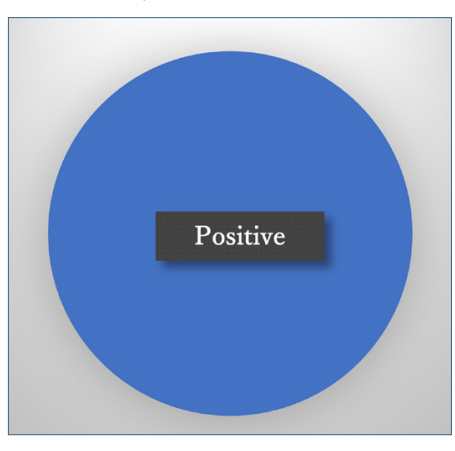

Yamamoto \& Teaman: Students' Views on ICT for English Learning During the Pandemic

Table 4

Sample Comments on Devices

\begin{tabular}{lcl}
\hline Name & iPads: Positive & \multicolumn{1}{c}{ iPads: Negative } \\
\hline Yoko & - & $\begin{array}{l}\text { With the iPad, I could not use } \\
\text { certain Word functions, } \text { and it's big }\end{array}$
\end{tabular}

Ami

Figure 2

On Computers

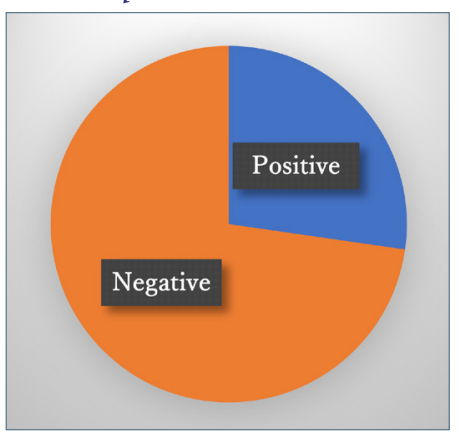

Mie
I have no difficulty using an iPad. because I have been using it for the past year.

It's easy to operate an iPad.

I can teach iPad related skills to someone.

Chie $\quad$ I can type well on the iPad.

Seiko The iPad is so handy, simple, and easy to use.

\begin{tabular}{ll}
\hline Name & \multicolumn{1}{c}{ Computers: Positive } \\
\hline Seiko & Computer is useful for printing \\
& things.
\end{tabular}

Yoko

I primarily used the computer when doing some research and writing notes.

Chie

Mie
There are things only a PC can do. and heavy.

The problem I had with the iPad was that sometimes, I could not open the file later, or a report disappeared.

The negative point about the iPad is that sometimes, it freezes and all the work is suddenly gone.

$$
-
$$

Computers: Negative
I use a computer only for printing
things. I don't know how to use a
computer.

I use a PC only when I have to. Computers are so cumbersome.

I have a hard time operating the PC because my hands are too small for a PC keyboard, so I am really inefficient with PC. 


\section{JALT2020}

COMMUNITIES OF
TEACHERS \& IEARNERS
Name

Smartphones: Positive

Seiko and $\underline{I}$ can use my iPhone wherever I am.

others

Impact of ICT on English Learning and English Learning Motivation

The numbers of positive comments for both ICT's Impact on English learning and English learning motivation were larger than negative comments, but the differences were not statistically significant. As for ICT's positive impact on English learning, a strong indicator seems to be "taking leadership out of necessity," as expressed by Yoko and Seiko. Ami, Mie, and Chie also talked about their spontaneous attitudes which were cultivated in online classes. Negative comments that may hinder English learning centered mainly on some typical problems that may happen during on line classes, such as delayed responses and overlapping voices. Concerning English learning motivation, positive comments on English learning apps and learning through music and movies for out-of-class learning were expressed by all. On the other hand, some students reported lower motivation because of their inability to understand the contents of the class or the lack of friendly rivalries which they benefited from in physical classrooms.

Table 5

Impact of ICT on English Comments Coding

\begin{tabular}{lccc}
\hline $\begin{array}{l}\text { Comment } \\
\text { Polarity }\end{array}$ & $\begin{array}{c}\text { ICT's impact on English } \\
\text { learning }\end{array}$ & $\begin{array}{c}\text { ICT's impact on English } \\
\text { learning motivation }\end{array}$ & Total \\
\hline Positive & $37(51 \%)$ & $20(59 \%)$ & $57(54 \%)$ \\
Negative & $35(49 \%)$ & $14(41 \%)$ & $49(46 \%)$ \\
Total & $72(100 \%)$ & $34(100 \%)$ & $106(100 \%)$ \\
\hline
\end{tabular}

Figure 4

ICT's Impact on English Learning

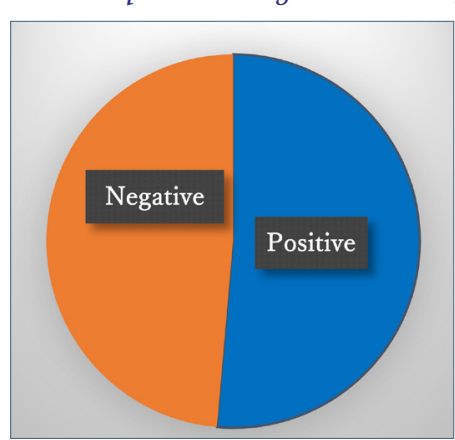

Figure 6

Total

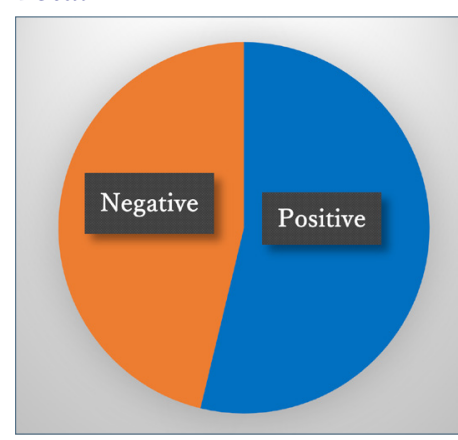

Figure 5

ICT's Impact on English Learning Motivation

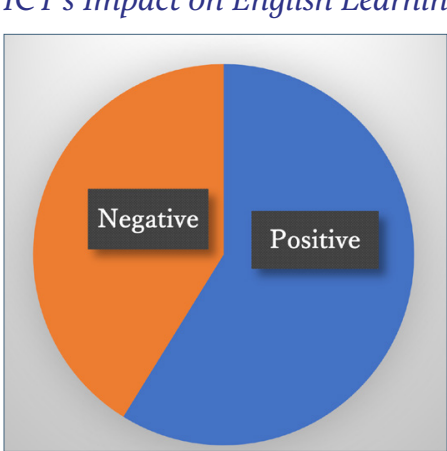


Table 6

Comments About the Impact of ICT on English for Each Participant

\begin{tabular}{lccccccccccc}
\hline & \multicolumn{2}{c}{ Yoko } & \multicolumn{2}{c}{ Ami } & \multicolumn{2}{c}{ Mie } & \multicolumn{2}{c}{ Seiko } & \multicolumn{2}{c}{ Chie } \\
\hline $\begin{array}{l}\text { ICT's Impact } \\
\text { on }\end{array}$ & $\mathrm{P}$ & $\mathrm{N}$ & $\mathrm{P}$ & $\mathrm{N}$ & $\mathrm{P}$ & $\mathrm{N}$ & $\mathrm{P}$ & $\mathrm{N}$ & $\mathrm{P}$ & $\mathrm{N}$ \\
$\begin{array}{l}\text { English } \\
\text { learning }\end{array}$ & 5 & 0 & 14 & 10 & 9 & 14 & 2 & 4 & 7 & 7 \\
English & 9 & 3 & 4 & 0 & 1 & 5 & 1 & 1 & 5 & 5
\end{tabular}

learning

motivation

$\begin{array}{lcccccccccc}\text { Total } & 14 & 3 & 18 & 10 & 10 & 19 & 3 & 5 & 12 & 12 \\ \text { Fisher's Exact } & 0.515 & 0.265 & 0.633 & 1 & 1 & 0.515 & 0.265 & 0.633 & 1 & 1\end{array}$

Test ( $p$ value)

Note. $\mathrm{P}=$ positive comments, $\mathrm{N}=$ negative comments.

Table 7

Sample Comments on the Impact of ICT on English

\begin{tabular}{|c|c|c|}
\hline \multicolumn{3}{|c|}{ ICT's impact on English learning } \\
\hline Name & Positive & Negative \\
\hline Yoko & $\begin{array}{l}\text { If nobody spoke and we couldn't get } \\
\text { our work done, I managed to take } \\
\text { leadership. }\end{array}$ & - \\
\hline Ami & $\begin{array}{l}\text { Our teacher chose the leader, but } \\
\text { when the group work did not go } \\
\text { smoothly, } 1 \text { helped the leader a lot as } \\
\text { I am good at working with others. }\end{array}$ & $\begin{array}{l}\text { Our English project did not go } \\
\text { smoothly as it took time to wait for } \\
\text { e-mail replies. Some students were } \\
\text { never able to be contacted. }\end{array}$ \\
\hline Mie & $\begin{array}{l}\text { When no one answered in online } \\
\text { classes, I didn't have courage at first, } \\
\text { but I finally raised my hand. }\end{array}$ & $\begin{array}{l}\text { When I didn't understand, I asked } \\
\text { questions by mail, but not in detail, } \\
\text { and in the mail, responses did not } \\
\text { come quickly, and explanations } \\
\text { were hard to understand. }\end{array}$ \\
\hline
\end{tabular}

\section{Seiko If there weren't any students who would take the leadership, $\underline{\text { became }}$ the leader, because I had to.}

Chie

When there were only three students who spoke up, I felt I had to.

\begin{tabular}{|c|c|c|}
\hline \multicolumn{3}{|c|}{ ICT's impact on English learning motivation } \\
\hline Name & Positive & Negative \\
\hline Yoko & $\begin{array}{l}\text { I spent a lot of time watching } \\
\text { animation and dramas on Netflix } \\
\text { and YouTube. Some of my friends }\end{array}$ & $\begin{array}{l}\text { My motivation shrank as classes } \\
\text { became harder to understand. I } \\
\text { didn't know what's going on. }\end{array}$ \\
\hline
\end{tabular}

complain that their English got rusty

because of online classes, but I don't think mine has declined.

Ami One thing I enjoyed was learning vocabulary with e-learning apps, on my way to my part-time job, or watching dramas and movies on Netflix.

Mie I took one Study Suppli course during Spring term. I learned basic grammar. I'm glad I did it.

Seiko I studied with some YouTubers'. "Study with me" channels, They motivated me to study.

Chie The app (English Central) shows ranking. I felt motivated when I was competing with my friends.
It was hard to find the right timing to speak, When nobody talked, it was very hard to keep the discussion going.

We didn't see each other, so when someone spoke up, her voice sometimes overlapped with someone else. It was hard to speak up. didn't know what's going on.

I was worried that my class performance would be lower because I could hardly speak in online classes. I was afraid I might fail classes.

I did not understand what was going on during online classes. I had indescribable feelings.

When I saw my friends studying hard, I felt motivated. I missed this friendly rivalry. 


\section{JALT2020}

COMMUNITIES OF
TEACHERS \& IEARNERS
Impact of ICT in General and ICT's Impact on Motivation in General

For both ICT's impact in general and its impact on general motivation, negative comments were greater than positive comments, although the differences were not statistically significant. Positive comments on ICT's impact in general centered around the participants' confidence in the skills they gained during Spring term. Negative comments were mostly about physical issues such as eye strain and bad posture. Mie and Chie mentioned the confusing system of online classes that may be improved by careful planning on the part of teachers.

As for motivation in general, positive comments mainly referred to students' renewed awareness of the positive aspects of ICT. Overcoming fear of using ICT (Seiko and Chie) can lead to increased motivation.

Table 8

Impact of ICT in General Comments Coding

\begin{tabular}{lccc}
\hline $\begin{array}{l}\text { Comment } \\
\text { Polarity }\end{array}$ & ICT's impact in general & $\begin{array}{c}\text { ICT's impact on } \\
\text { motivation }\end{array}$ & Total \\
\hline Positive & $23(28 \%)$ & $12(41 \%)$ & $35(31 \%)$ \\
Negative & $60(72 \%)$ & $17(59 \%)$ & $77(69 \%)$ \\
Total & $83(100 \%)$ & $29(100 \%)$ & $112(100 \%)$ \\
\hline
\end{tabular}

Figure 7

ICT's Impact in General

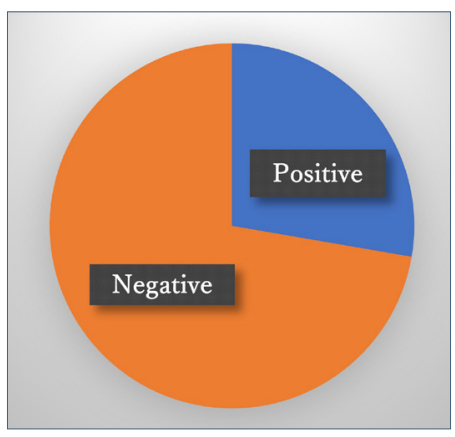

Figure 8

ICT's Impact on Motivation in General

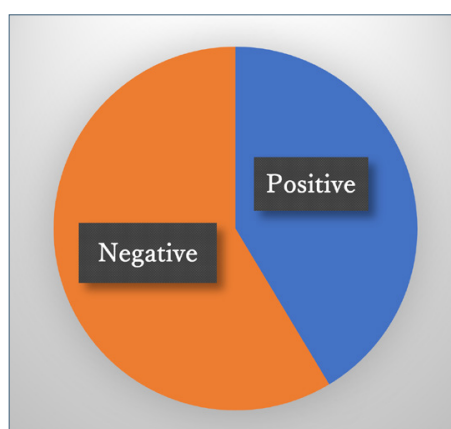

Figure 9

Total

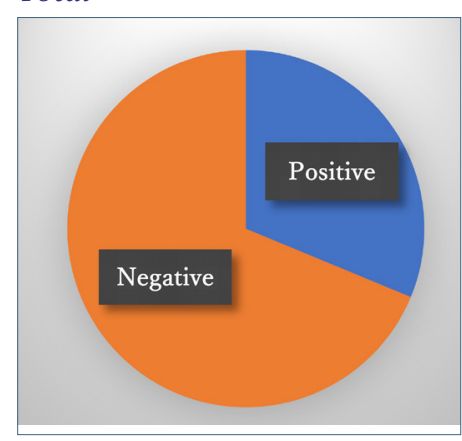

Table 9

Impact of ICT in General Comments Coding by Participants

\begin{tabular}{lcrrrrrrrrr}
\hline & \multicolumn{2}{c}{ Yoko } & \multicolumn{2}{c}{ Ami } & \multicolumn{2}{c}{ Mie } & \multicolumn{2}{c}{ Seiko } & \multicolumn{2}{c}{ Chie } \\
\hline ICT's Impact & P & N & \multicolumn{1}{c}{ P } & N & P & N & P & N & P & N \\
\hline In general & 6 & 9 & 4 & 7 & 2 & 14 & 3 & 11 & 8 & 19 \\
On motivation & 1 & 1 & 1 & 0 & 1 & 6 & 8 & 5 & 1 & 5 \\
Total & 6 & 11 & 4 & 7 & 3 & 20 & 11 & 16 & 9 & 24 \\
Fisher's Exact & \multicolumn{2}{c}{1} & \multicolumn{2}{c}{0.417} & \multicolumn{2}{c}{1} & & 0.054 & \multicolumn{2}{c}{0.054}
\end{tabular}

Test ( $p$ value)

Note. $\mathrm{P}=$ positive comments, $\mathrm{N}=$ negative comments. 
Table 10

Sample Comments on Impact of ICT in General Comments

\begin{tabular}{|c|c|c|}
\hline \multicolumn{3}{|c|}{ ICT's impact in general } \\
\hline Name & Positive & Negative \\
\hline Yoko & $\begin{array}{l}\text { During online classes, } \underline{\mathbf{I} \text { had to type }} \\
\text { a lot, so I got more skillful in typing } \\
\text { and formatting, indenting, and so } \\
\text { forth with Word. }\end{array}$ & $\begin{array}{l}\text { My posture got worse. I tried to keep } \\
\text { a good posture, but if I studied for a } \\
\text { long time, I got distracted. }\end{array}$ \\
\hline Ami & $\begin{array}{l}\text { My ICT skills have leveled up, } \\
\text { especially typing skills thanks to } \\
\text { online classes. }\end{array}$ & $\begin{array}{l}\text { As I couldn't sleep well at night, I } \\
\text { was sleepy during classes. } \\
\text { Eye strain was terrible as I looked } \\
\text { at the screen for a long time. I felt } \\
\text { lonely, too. }\end{array}$ \\
\hline Mie & $\begin{array}{l}\text { I tried to make the best use of my } \\
\text { online classes schedule, managing } \\
\text { my spare time effectively. }\end{array}$ & $\begin{array}{l}\text { One trouble I had during online } \\
\text { classes was, the places to submit } \\
\text { my assignment were different } \\
\text { depending on classes. It was } \\
\text { troublesome. }\end{array}$ \\
\hline Seiko & $\begin{array}{l}\text { I got so skillful thanks to online } \\
\text { classes because } \mathbf{I} \text { had to learn all by } \\
\text { myself. }\end{array}$ & $\begin{array}{l}\text { Sometimes, the Internet connection } \\
\text { got bad. }\end{array}$ \\
\hline Chie & $\begin{array}{l}\text { I had to do everything on my own, } \\
\text { so I am better at handling apps and } \\
\text { zoom, and so on. }\end{array}$ & $\begin{array}{l}\text { My eyes got tired. } \\
\text { One negative point about online } \\
\text { classes was that teachers conduct } \\
\text { classes differently and sometimes we } \\
\text { were not informed well about our } \\
\text { next class. }\end{array}$ \\
\hline
\end{tabular}

\begin{tabular}{lll}
\hline & ICT's impact on motivation in general & \\
\hline Name & Positive & Negative \\
\hline
\end{tabular}

Yoko If you lack ICT skills, in classes, it would affect your performance, like Word, or other things, then you will get demotivated, so I think ICT skills are necessary.

Ami E-learning, especially learning apps are so useful and handy, because don't have to carry heavy books. I don't read paper books any more.

Mie Once I learned to manage my time well, online classes became more enjoyable.

Seiko I think online classes helped me overcome my fear of ICT. I think I developed challenging spirit during the Spring term in learning ICT skills, English learning, taking leadership, and so on.

\section{Chie I overcame my fear of speaking} during the Spring Term, when I couldn't see anyone's faces and when I felt nervous. I felt like I could do better once face-to-face classes start.

My motivation got lower because other than the fact that I don't have to commute, there is no merit in online classes. Now I feel like I am really learning [in face-to-face classes].

\section{Learning with analog texts and} writing in notebooks are much more motivating for me than eBooks and apps.

Staying at home all day in front of

PC was very depressing. I almost got sick. I could not concentrate well,

and my motivation got lower and lower.

When I didn't have to go to school, I was a little lazy. I tended to lie down. I got nervous in face-to-face classes, which is more motivating to me.

\section{Discussion}

As for the preferred device to use during online classes, iPad-based education as employed in the university was favored as is reflected in the results. Comments about PCs showed that the interview participants were not used to using computers.

We conducted a survey at the beginning of the fall term of 2020 which asked about the devices students used during the same period. The number of survey participants was 74 


\section{JALT2020}

COMMUNITIES OF
TEACHERS \& IEARNERS

(first year $=11$, second year $=25$, third year $=34$, fourth year $=4$ ). All survey participants gave informed consent, and the project was cleared with the university's institutional review board. Figure 8 shows the popularity of iPads. The results were the same as the interview participants' answers.

Figure 10

Devices Used by Participants $(N=74)$ For Online Courses During the 2020 Pandemic.

\begin{tabular}{|c|c|c|}
\hline \multicolumn{3}{|l|}{$100 \%$} \\
\hline & $68 \%$ & \\
\hline iPads & Smartphones & Computers \\
\hline
\end{tabular}

The school's emphasis on the use of iPads for day-to-day learning both inside and outside of the class helped students (both interviewed and surveyed) make a smooth transition from face-to-face to online learning. However, it became clear students were not as adept at using computers.

Regarding "Impact of ICT on English Learning and English Learning Motivation," difficulty speaking during online classes could be considered a common issue among students studying online. We need to think of ways to avoid overlapping of speakers by providing ground rules for online discussion. Discussions in small groups or pairs should be conducted utilizing the functions of online platforms. On the positive side, participants managed to take some forms of leadership out of necessity. These students generally described themselves as not the type to take leadership voluntarily. Their online leadership experience will hopefully have a positive effect on their regular face-toface classes.

In terms of motivation, all participants engaged in their outside-of-class study through entertainment-type means such as YouTube videos and online movies and language learning apps. Yoko expressed confidence in listening skills as a result of extensive listening activities. Her TOEIC ${ }^{\circ}$ score improvement (see Table 1 ) can partly be explained by her effort. What was missing from their out-of-class learning schedule were reading exercises. None continued the online reader program, Xreading, which was part of the requirement in their previous year nor did they engage in any extensive reading activities.

As for "ICT's Impact in General and ICT's Impact on General Motivation," as ICT's Impact in General (Table 10) shows, students seem to have taken ownership of online learning by the end of the Spring term through building ICT skills. Even so, all students expressed that they preferred face-to-face courses. Some comments were about their dissatisfaction about class management. Good communication among faculty as well as between teachers and students are essential especially for online classes.

We provide a brief discussion of each of the research questions as follows.

1. How do students characterize ICT use for English learning during the emergency online Spring term?

This study found that ICT provided useful tools for students during the remote learning period. ICT, namely, learning devices and LMS (Learning Management System), were used effectively for class and independent language study. The vocabulary learning app that is preinstalled on students' devices and other apps of students' choices were utilized. However, the online extensive reading program that school offers (Xreading) was not popular.

2. How have students' ICT skills changed during the online Spring term?

Interviews confirmed that the students felt they had built up confidence because of improved ICT skills.

3. Which devices did students utilize for their remote classes?

The primary device for online education was the iPad and smartphones were also widely employed.

4. What impact did the online Spring term courses have on students' motivation to study English?

The impact on motivation to learn was generally positive, although demotivating factors were also observed. The lack of interaction with their peers and teachers, the strain of online-only classes in terms of health and connectivity were some of the possible causes of demotivation. The Out-of-class study they reported was mainly 
vocabulary learning using apps and study-while-having-fun type learning such as listening to Western music and watching movies.

\section{Conclusion}

Interview data of this study generally confirmed that, due to students' ICT proficiency, they have successfully gone through the emergency online semester and eventually improved their English-learning motivation. However, we found issues that could lead to demotivation. In the future, we need to discuss ways to make sure students receive proper educational and technical support from teachers and ICT staff whenever necessary. Furthermore, measures to minimize health issues should be in place.

Interviewees chose the iPad as their primary device to aid learning. Despite learners having Information Technology classes where they can learn how to use computers, their computing skills were not as strong as their iPad skills. More emphasis needs to be placed on computer skills so that they can meet the demands of society.

This study is limited due solely to interviewing second-year students. It is highly likely that the first-year students who were new to technology encountered challenges adapting to the new learning style. Follow-up interviews with them will examine both the positive and negative impacts of their experiences. Furthermore, the study is limited because of the limited number of participants. The findings could also be compared with data from other schools that offer different devices or learning platforms.

Whether online or face to face, the key to future success will be to plan and provide good lessons deliverable in either way. For this purpose, we will continue to listen to students' voices so that we can respond to what really matters to them.

\section{Acknowledgements}

Our thanks go to Dr. Tamara Swenson and Dr. Iguchi Yutaka for their comments and suggestions on this manuscript. Part of this study was supported by a JSPS Grant-in-Aid for Scientific Research (C), Grant Number 18K00900.

\section{Bio Data}

Junko Yamamoto has been with Osaka Jogakuin University since 2019. Her fields of study include second language acquisition and learners' motivation. yamamoto@ wilmina.ac.jp

Brian Teaman has been with Osaka Jogakuin University since 2004. His fields of study include phonetics, L2 pronunciation/speaking, and CALL. teaman@wilmina.ac.jp

\section{References}

Agresti, A. (2002). Categorical data analysis (2nd ed.). Wiley.

Cummings, M.C. (2004). "Because we are shy and fear mistaking": Computer mediated communication with EFL writers. Journal of Basic Writing, 23(2), 23-48. Available from http:// www.jstor.org/stable/43444066

Furnham, A., \& Marks, J. (2013). Tolerance of ambiguity: A review of the recent literature. Psychology, 4(9), 717-728. http://dx.doi.org/10.4236/psych.2013.49102

Ritchie, M., \& Black, C. (2012). Public Internet forums: Can they enhance argumentative writing skills of second language learners? Foreign Language Annals, 45(3), 349-361. https://doi. org/10.1111/j.1944-9720.2012.01203.x

Strauss, A., \& Corbin, J. (1998). Basics of qualitative research: Techniques and procedures for developing grounded theory. Sage.

Swenson, T., Bramley D., \& Cornwell S. (2014). Making interactive eBooks: More than just cutting and pasting. Journal of Osaka Jogakuin University,10, 17-30. Available from http://ir-lib.wilmina. ac.jp/dspace/handle/10775/3127

Ushioda, E. (2013). Motivation matters in mobile language learning: A brief commentary. Language Learning \& Technology, 17(3), 1-5. Available from http://wrap.warwick.ac.uk/57499/

Warschauer, M., \& Healey, D. (1998). Computers and language learning: an overview. Language Teaching, 31(2), 57-71. http://dx.doi.org/10.1017/S0261444800012970

Yamamoto, J. (2020a). Motivational effects of ICT on Japanese EFL Students. Media, English and Communication, 10, 7-29.

Yamamoto, J. (2020b). ICT を中心とする英語教育を受けた学生の意識に関する質的研究 [A qualitative study of four university students' attitudes toward ICT-based English education]. 日本教科教育 学会誌 [The Bulletin of Japanese Curriculum Research and Development], 43(3), 1-13. https://doi. org/10.18993/jcrdajp.43.3_1 


\section{JALT2020}

TEACHERS \& LEARNERS

\section{ICT Use Survey}

Which devices did you use during your online classes and outside the classroom study during the Spring term of 2020 ? Check all that apply.

春学期に授業中、授業外の英語学習にどのデバイスを使用しましたか。当てはまるものすべてに

チェックを入れてください。
$\square \mathrm{iPad}$
$\square$ Personal Computer
$\square$ Smartphone
$\square$ Others

Yamamoto \& Teaman: Students' Views on ICT for English Learning During the Pandemic

\section{Appendix}

